\title{
Accounting Students' Perception on Pursuing Professional Examination
}

\author{
Mazlina Mustapha* ${ }^{1} \&$ Mohammad Hasmawi Abu Hassan ${ }^{1}$ \\ ${ }^{1}$ Faculty of Economics and Management, Universiti Putra Malaysia, 43400 UPM, Serdang, \\ Selangor, Malaysia
}

*Corresponding author: Mazlina Mustapha, Faculty of Economics and Management,Universiti Putra Malaysia, 43400 UPM, Serdang, Selangor, Malaysia

Tel: 60-3-8946-7636_Email: mazlina05@gmail.com

Received: March 22, 2012 Accepted: July 26, 2012 Online Published: October 7, 2012

doi:10.5296/ije.v4i4.1546 URL: http://dx.doi.org/10.5296/ije.v4i4.1546

\begin{abstract}
Prior studies indicate that people's perception have an important influence on their career decisions. This study explores the accounting students' perceptions on professional examination and the factors that influence their decisions to take the exam. Questionnaires were distributed to final year accounting students of a public university in Malaysia. About 103 questionnaires were completed and usable for the purpose of the study. Regression analysis was employed to analyse the data. The results indicate that about $70 \%$ of the respondents plan to work immediately after graduating, and only about $28 \%$ of the respondents really have the intention to pursue professional qualification. Among others, the findings reveal that the job security and stability, and opportunities for advancement as well as the students' perception towards the profession are the three main variables found to be significant in influencing the accounting students' decision to pursue professional examination. The results of the study appear to suggest that the educators and universities must play their role to positively influence and motivate the students to pursue professional examination. The favourable information about the profession may attract the potential students to take the challenge.
\end{abstract}

Keywords: accounting students, professional examination, accounting profession

\section{Background of the study}

Globalisation has brought about many changes in the accounting profession. In addition, the corporate scandals in the US and Europe, have resulted in a challenge to the accounting 
profession's integrity, professional conducts and responsibility to the public. Therefore, there is a need for the accounting industry to ensure that it continuously maintain a strong reputation and the highest standard of professionalism. To meet these challenges, the accounting education must be in line with these changes, in order to ensure that the students are prepared to face the world upon graduation.

Among others accounting graduates are encouraged to take professional accounting examination to raise their competency to be on the same level and playing field with foreign accountants (MIA wants accountants, 2004). This notion is supported by Malaysian Institute of Accountants (MIA), a statutory body established to regulate and develop the accountancy profession in Malaysia, a developing country in Asia. According to MIA, this would ensure that the accounting profession in Malaysia has well-qualified individuals, especially when the demand for the qualified accountants is high to help developing the economy of the country. It is claimed that Malaysia needs 60,000 accountants by the year 2020, however more than half of this is not met yet (Lanson, 2010). There has also been some concern regarding the number of accounting graduates who fail to pursue further studies to gain higher professional accounting qualification (Malaysia lacked of certified accountants, 2009; Lanson, 2010). It is claimed that out of 25,000 accountants, only 600 of them have professional qualification (Malaysia lacked of certified accountants, 2009). In addition, it is also claimed that only 30 percent of accounting graduates are truly practicing accounting. This situation may affect the government's goal to have at least 60,000 professional accountants in Malaysia by the year 2020 (Abdullah, 2001).

Thus, this study is conducted to examine the factors that influence accounting students' career intention to become professional accountants in Malaysia. This study can provide information to the universities and Ministry of Higher Learning, and help them to arrange for the possible training to encourage the graduates to take the examination. In addition, this study also can be a source for the professional bodies to decide on the strategy on how to increase the number of professional accountant in Malaysia. This also will contribute to the future viability of professional bodies because it is claimed that the future viability of any professional body depends on their ability to continuously attracting new members, ideally the best and the brightest new tertiary graduates (Malthus, and Fowler, 2009).

\section{Literature review}

Previous studies have investigated various reasons which influence the graduates' career decisions in professional accounting (Sugahara et al., 2008; Kloot et al, 2007; Said et al., 2004; Omar, 2009). Among the factors being discussed were the experienced of the students (Sugahara et al., 2008), the offered salary (Said et al., 2004), gender differences (Kloot et al, 2007; Ahmadi et al, 1995; Omar, 2009), and the students perception of professional qualification (Sugahara et al., 2008; Omar, 2009; Kloot et al, 2007).

Previous studies claim that salary is one of the most important factors that will affect the graduates' decision on career choice. This notion is supported by many studies conducted in Malaysia as well as outside Malaysia. One of the studies reports that, starting salary is an important criterion for choosing accounting as a career (Said et al, 2004). Salary is also a 
hygiene factor that motivates an individual (McLean, Smits and Tanner, 1996). This is supported by Horowitz and Riley (1990) who claim that one of the top criterions that influence students' career decision is salary offered to them. Another study by Trump and Hendrickson (1970) finds that starting salary is one of the major job characteristic preferences by undergraduate accounting majors and this factor is ranked on top five with the mean ranking 6.94. A study by Carpenter and Strawser (1970) finds that one of the preferences on job selecting among accounting students is the starting salary. However, there are also studies which reveal contradicting findings, such as Cottrel (2011). Cottrel claims initially, salary is ranked highly, but as time passes, other factors tend to crowd out salary in its importance.

Another variable which is claimed to influence the students' career choice decision as professional accountants is the opportunity for advancement in the profession. Carpenter and Strawser (1970) find that the opportunities for advancement are better in accounting fields compared to other fields. These opportunities give them the challenges to prove that they can do the job. A local study by Said et al. (2004) finds that this factor ranks high in influencing the choice of career in accounting among Malaysian students. Another study by Ahmadi et al. (1995) finds that career advancement is also a leading factor for females accounting students in their job selection decision. This is supported by another study by Trump and Hendrickson (1970) which finds that this factor is one of the most important considerations in the accounting students' career decision and it is listed as either the first or second most important criterion in their career choice criteria.

Other researchers have pointed out that a deficiency of information and sometimes misinformation on what an accountant actually does could be one of the primary factors affecting student's career aspirations (Albrecht and Sacks, 2000). One of the factors that normally accounting students would consider in their decision is their perception towards the profession (Omar, 2009). Some accounting students think that it is tough and difficult to pass the professional accounting programmes and just few finalists passed with only one attempt (Omar, 2009). This is consistent with a study conducted in New Zealand which has concluded that tertiary students as well as high school teachers perceive accounting to be dull and boring (Malthus and Fowler, 2009). The students view accounting as a dull subject and accountants are introverted and not very fun to be around, as they sit down at a desk all day and calculate numbers, they have poor social skills and do not do many things outdoors, not outdoorsy people and they lack a sense of humour (Malthus et al, 2009).

Jackling (2002), examined Australian undergraduate students and discovered that skewed images toward the accounting profession has led to a failure in attracting students with creativity and people-oriented personalities that are so desperately sought by the profession. Some students also believed that professional accounting programmes are tougher than degree programmes, thus it is only suitable for those who are disciplined and highly committed students, and only those with excellent cumulative grade point aggregate (CGPA) can pursue professional accounting programmes (Omar, 2009). Some students feel that it is better for them to pursue other programmes rather than professional accounting programmes because of these perception that they heard, especially about the number of attempts that 
most of the professional accounting students needed to make in order to complete the professional study (Omar, 2009). This shows that students still have bad perception toward the professional accounting programmes especially among the Malay students at the higher education institutions (Abdullah, 2001). Students perceived that the examination is difficult and they may need to make a few attempts to pass the exam (Abdullah, 2001).

Sugahara and Bolland(2006) replicated overseas study techniques and investigated possible relationships between vocational factors and perceptions among students studying in the tertiary schools but not in the accounting schools. Their findings revealed that non-CPA students tend to view the CPA as a profession with low communication skills; poor career prospects and being very much male dominated. Although this exploratory study simply compared statistical differences in perceptions of the CPA between students who wanted to become a CPA and those who did not, it has provided important implications to our understanding of this dichotomy where influence factors can determine a CPA career.

Perceived prestige or social status is one of the five factors studied in determining choice of an accounting major used by Steadman and Huang (1996). Wheeler (1983) in his study reported that all students from business, psychology and education agree that the supply of jobs in accounting is better than in other areas of business. Accountant generally holds a positive view on the accounting profession, while non-accountants view the profession more negatively (Oswick et al, 1994). Another study by Ahmadi et al (1995) finds that job security and stability is one of the factors that is of concerned, especially by the female accountants. However, this finding contradicts another study by Miller and Wheeler (1992) who finds that job security is not a significant factor in influencing the students' career choice decisions.

\section{Methodology}

Data used in this study was collected using primary source. Questionnaires were distributed and interviews were conducted to better understanding the issue of the study.

The questionnaire used in this research was adapted from Omar (2009). Questionnaires were distributed to 120 final year accounting students in a public university in Malaysia. The final year accounting students are chosen because it is believed that after being in the university for a number of years, and have taken most of the important accounting courses, they would have a better and clearer understanding and expectations of their career choices. Besides that, the final year accounting students also will need to decide on the job selection very soon compared to the first, second or third year students. About 103 questionnaires were returned and usable for the study. The questionnaire consists of three parts. Part A attempts to solicit the respondents' future plan after graduation, Part B tries to obtain information about the factors that influence their career intention after graduating and their intention to pursue professional examination, and Part C seeks information about the respondents' socio-demographic.

In addition, a number of respondents were selected for interviews to better understand their reasons for taking or not taking the professional examination. 
3.1 Proposed model for the study

The information for the variables used in this study was obtained from the items in the questionnaire. These items are listed in Table 3. These items are reduced to five factors using the factor analysis. The five factors are job security and stability, status or prestige of having a professional qualification, opportunities of advancement for having the professional qualification, salary for professional accountants and accounting students' perception of accounting profession.

The data is checked for reliability, validity, normality, and multicollinearity. Regression analysis is used to analyse the data.

The proposed model for the study is shown below:

Where;

$$
\mathrm{IPPE}=\alpha+\beta 1 \mathrm{SLR}+\beta 2 \mathrm{OFA}+\beta 3 \mathrm{STPR}+\beta 4 \mathrm{PRTG}+\beta 5 \mathrm{JSS}+\varepsilon
$$

$\begin{array}{ll}\text { IPPE } & =\text { Intention to pursue professional examination } \\ \alpha & =\text { intercept } \\ \text { SLR } & =\text { Salary } \\ \text { OFA } & =\text { Opportunities for advancement } \\ \text { STPR } & =\text { Students' perception } \\ \text { PRTG } & =\text { Prestige or status } \\ \text { JSS } & =\text { Job security and stability } \\ \varepsilon & =\text { Errors }\end{array}$

\section{Results and discussions}

\subsection{Profile of respondents}

Table 1 presents the profile of the respondents. As expected, majority of the respondents are female because of the current phenomena in the institutions of higher education where female students are more than male students (Said et al, 2004). About $69.9 \%$ of the respondents are female and most of them $(96.2 \%)$ are single.

A total of $71.8 \%$ of the respondents are Malays, and 25.2\% are Chinese. Only $2.9 \%$ are Indian respondents. Most of the respondents (59.8\%) have CGPA between 3.00 and 3.49. 


\section{Mll Macrothink}

Table 1: Demographic information

\begin{tabular}{lcc}
\hline Demographic factors & $\mathbf{n}$ & $\mathbf{\%}$ \\
\hline Gender: & 31 & 29.5 \\
Male & 72 & 68.6 \\
Female & & \\
Marital status: & 101 & 96.2 \\
Single & 2 & 1.9 \\
Married & & \\
& & \\
Race: & 74 & 70.5 \\
Malay & 26 & 24.8 \\
Chinese & 3 & 2.9 \\
Indian & & \\
CGPA: & 12 & 11.4 \\
2.50 to 2.99 & 61 & 59.8 \\
3.00 to 3.49 & 29 & 27.6 \\
3.50 to 4.00 & & \\
\hline
\end{tabular}

\subsection{Future planning after graduation}

Table 2 shows the respondents' responses relating to their future planning after graduation. The first row of Table 2 reports that, close to $70 \%$ of the respondents would like to work immediately after graduation. Another $30 \%$ of the respondents would like to pursue their studies after graduation.

The second row of Table 2 shows that only 29 respondents $(28.2 \%)$ indicate their interest to obtain professional qualification after they graduate. More than $65 \%$ of the respondents indicate that the possibility of them taking the professional examination is probable only. The remaining 5 respondents show that it is unlikely for them to take the professional examination.

During the interview, these are the responses by the respondents who intend to take the professional examination:

"Professional exam is challenging"

"I want to be a professional and get more salary"

"Professional accountant is highly valued by the society"

"Taking and passing professional examination will increase my confidence."

"To be more marketable and get higher salary" 


\section{Macrothink}

Table 2: Future plan after graduation

\begin{tabular}{|c|c|c|c|}
\hline & & $\mathbf{n}$ & $\%$ \\
\hline What do you plan to do after & To work immediately after & 73 & 69.5 \\
\hline \multirow[t]{2}{*}{ graduating? } & graduating & 30 & 30.5 \\
\hline & To further study & & \\
\hline \multirow{2}{*}{$\begin{array}{c}\text { Do you have an intention to } \\
\text { pursue }\end{array}$} & Certainly & 29 & 27.6 \\
\hline & Probably & 69 & 65.7 \\
\hline \multirow[t]{2}{*}{ professional qualification? } & Unlikely & 5 & 4.8 \\
\hline & ACCA & 73 & 69.5 \\
\hline \multirow{5}{*}{$\begin{array}{c}\text { If you have to make a choice, } \\
\text { which professional } \\
\text { programme would you } \\
\text { choose? }\end{array}$} & CIMA & 22 & 21.4 \\
\hline & MICPA & 4 & 3.8 \\
\hline & CPA Australia & 2 & 1.9 \\
\hline & $\mathrm{CIA}$ & 2 & 1.9 \\
\hline & From the lecturer & 47 & 44.8 \\
\hline \multirow{4}{*}{$\begin{array}{c}\text { How did you become aware } \\
\text { of the professional } \\
\text { programmes? }\end{array}$} & Seminar/Workshop/Exhibition & 44 & 41.9 \\
\hline & Career guide from counselling unit & 4 & 3.8 \\
\hline & Advertisement from newspaper & 4 & 3.8 \\
\hline & Notice board at university & 2 & 1.9 \\
\hline
\end{tabular}

The following are the responses by those who claim that probably they would take the professional examination:

"Depends, if I do not get any job offer, then maybe I would pursue my study and take professional exam, possibly passing the exam will help me to get job".

"Depends on the situation, if the job requires me to take the exam, I may consider it."

"Depends on the career opportunity and the costs involved"

"May be, I will decide after I start working"

"Possibly, if I have enough money"

The following are the responses by those who do not intend to take the examination:

"It will take a long time to pass the professional exam"

"Professional exam is difficult to pass and costly"

"I do not want to become a professional accountant because I do not plan to venture into the field of accounting". 
"The professional exam needs high commitment and need a lot of money."

In the third row of Table 2, the respondents are asked to choose which professional exam they would like to take if they are given a choice. More than majority of the students $(69.5 \%)$ indicate that they would choose ACCA. Another favourite professional examination among the respondents is CIMA with $21.4 \%$ respondents indicating their intention to take this examination.

During the interviews, the respondents were asked for their reason of choosing a specific professional examination. The following are some of their reasons on why most of them chose to pursue ACCA rather than other professional programmes.

"ACCA is accepted worldwide compared to some professional programmes".

"Those who have the ACCA qualification are more marketable or demanded by the industry”.

"You can gain more salary if you have ACCA qualification".

"I prefer financial accounting than management accounting"

In the last row of Table 2, the respondents claim that they mainly get the information about the professional examination from their lecturers $(44.8 \%)$ and accounting seminars which they attended (41.9\%).

\subsection{Students' perception of professional qualification}

Table 3 presents the descriptive statistics of the statements relating to the students' perception of the professional qualification.

Table 3: Descriptive statistic of the statements

\begin{tabular}{|c|c|c|c|}
\hline Variables & $\mathbf{N}$ & Mean & Std. Deviation \\
\hline Professional qualifications are highly valued by the public. & 103 & 4.24 & .720 \\
\hline $\begin{array}{l}\text { Accountants with professional qualifications are more } \\
\text { respected than accountants with degree in accounting. }\end{array}$ & 103 & 4.15 & .809 \\
\hline Professional titles are highly and internationally recognized. & 103 & 4.28 & .617 \\
\hline $\begin{array}{l}\text { Job as accountant is more flexible compared to others } \\
\text { professional job. }\end{array}$ & 103 & 3.22 & 1.028 \\
\hline $\begin{array}{l}\text { Job as accountant will confirm the job stability compared to } \\
\text { other professional career. }\end{array}$ & 103 & 3.45 & .860 \\
\hline Career as accountant are highly secured (Job Security) & 103 & 3.31 & .919 \\
\hline Accounting field have better opportunity to specialize. & 103 & 3.79 & .775 \\
\hline $\begin{array}{l}\text { Professional accountants will have better opportunities for } \\
\text { promotions to be in high level position in a company. }\end{array}$ & 103 & 4.04 & .713 \\
\hline $\begin{array}{l}\text { Accounting field is the professional field that provides better } \\
\text { training opportunities. }\end{array}$ & 103 & 4.01 & .679 \\
\hline $\begin{array}{l}\text { Accounting field will guarantee the bright of future } \\
\text { opportunities. }\end{array}$ & 103 & 3.73 & .865 \\
\hline
\end{tabular}


The professional accounting examination is not tough and

103

2.28

1.042

not so difficult to pass.

Accounting field is the very interesting professional field $\quad \begin{array}{ll}103 & 3.60\end{array}$

.844

compared to others.

Students with the excellent cumulative grade point

$103 \quad 2.35$

1.135

aggregate (CGPA) only can pursue professional accounting exam.

Only those who have degree in accountancy can pursue the professional accounting exam.

Professional graduated is paid higher salary than degree graduated.

High salary is my main factor why I choose to pursue professional exam after I graduated.

I can gain high salary if I have professional qualification.

Degree holder are paid less than professional qualification holder.

I will pursue the professional Qualification to become a

$103 \quad 2.98$

professional accountant after graduating.

Professional accountant will be my first priority in my career

$\begin{array}{lll}103 & 4.08 & .750\end{array}$

$103 \quad 3.86 \quad .960$

$\begin{array}{lll}103 & 4.04 \quad .862\end{array}$

$\begin{array}{lll}103 & 3.86 & .715\end{array}$

choice decision.

Career as professional accountant will be my best interest.

Professional exams scare me.

$103 \quad 3.58$

.814

I like the challenges when taking professional examination.

103

3.48

1.098

I hope to pass all the professional exam papers in one

$103 \quad 4.09$

.948

sitting.

Not enough to have degree in accountancy

103

3.15

.853

Professional qualification and non-professional qualification

103

3.70

.933

are valued differently by the public

Work as accountant will guarantee the security of the work

$103 \quad 3.03$

.968

Salary is my main factor in my career choice decision

$103 \quad 3.50$

.985

Other professional fields are not stable compared to

103

3.10

.979

accounting field

Work as banker is not flexible than work as accountant

It is not difficult to get promotion in accounting

$103 \quad 3.27$

.949

it is opportunities to specialize in accounting

$103 \quad 3.42$

.877

I am more preferred accounting field than other field

103

2.96

.823

Professional qualification holder are paid better than degree

103

3.82

holder

It is easy to pass the professional exam

Accounting field is very fun to be around

It is safer to pursue accounting program rather than other

$103 \quad 3.09$ 
4.4 Reliability and validity tests.

The reliability checked of the data indicates that the Cronbach's alpha is 0.801 , and acceptable as it is more than the threshold value of 0.80 (Ho, 2006, p.240). The value of Kaiser-Meyer-Olkin for the data is 0.656 which indicates that the factor analysis model is appropriate as the value is greater than 0.5 (Field, 2005).

\subsection{Normality and multicollinearity}

Table 4 reports the descriptive statistics of the variables used in the study. Overall, the data appears to be normally distributed as the skewness and kurtosis values are between \pm 3.00 (Kline, 2005, p.50).

Table 4: Descriptive Statistics

\begin{tabular}{|c|c|c|c|c|c|c|}
\hline & Minimum & Maximum & Mean & $\begin{array}{c}\text { Std. } \\
\text { Deviation }\end{array}$ & $\begin{array}{c}\text { Skewn } \\
\text { ess }\end{array}$ & Kurtosis \\
\hline Salary & 14.00 & 30.00 & 20.5340 & 2.16847 & .756 & 3.016 \\
\hline Job security stability & 12.00 & 26.00 & 18.6311 & 2.89011 & .310 & -.349 \\
\hline $\begin{array}{l}\text { Opportunities for } \\
\text { advancement }\end{array}$ & 17.00 & 31.00 & 23.5825 & 2.68081 & .489 & .827 \\
\hline Prestige or status & 13.00 & 25.00 & 17.8252 & 2.13939 & .287 & .790 \\
\hline Students' perception & 14.00 & 31.00 & 20.0777 & 3.85698 & .977 & .724 \\
\hline $\begin{array}{l}\text { Intention to pursue } \\
\text { professional examination }\end{array}$ & 17.00 & 33.00 & 24.2913 & 3.06988 & .105 & .015 \\
\hline
\end{tabular}

Table 5 presents the pairwise correlation coefficient of all the variables used in the study. The results indicate that there is no multicollinearity problem, as the correlations are below the threshold value of 0.8 (Gujarati, 2003, p. 359)

Table 5: Pearson correlation test for the variables

\begin{tabular}{lrrrrrr}
\hline & $\begin{array}{c}\text { Intention } \\
\text { to } \\
\text { pursue }\end{array}$ & Salary & $\begin{array}{c}\text { Job } \\
\text { security } \\
\text { stability }\end{array}$ & $\begin{array}{c}\text { Opportunities } \\
\text { for } \\
\text { advancement }\end{array}$ & $\begin{array}{c}\text { Prestige } \\
\text { status }\end{array}$ & $\begin{array}{c}\text { Students' } \\
\text { perception }\end{array}$ \\
\hline $\begin{array}{l}\text { Intention to pursue } \\
\text { professional }\end{array}$ & 1 & & & & & \\
examination & & & & & & \\
Salary & $0.247^{* *}$ & 1 & & & & \\
Job security stability & $0.269^{* *}$ & $0.248^{*}$ & 1 & & & \\
Opportunities for & $0.329^{* *}$ & $0.312^{* *}$ & .125 & & 1 & \\
advancement & & & & & & \\
Prestige status & $0.227^{*}$ & $0.337^{* *}$ & .124 & $0.472^{* *}$ & 1 \\
Students' perception & $0.183^{*}$ & -.049 & -.106 & $0.346^{* *}$ & $0.344^{* *}$ & \\
\hline
\end{tabular}

*Correlation is significant at the 0.01 level (2-tailed)

** Correlation is significant at the 0.05 level (2-tailed) 
4.6 Regression analysis

Table 6 presents the regression results of the study. The value of the adjusted R- Squared is 0.146 , with the $\mathrm{F}$ value of $4.492(\mathrm{p}<0.000, \mathrm{df}=5,97)$. This adjusted R-squared is similar to a study by Sugahara et al. (2008) which examines the factors that influence the accounting students in Japan and their career intention to be a CPA. Their study generates an adjusted R-squared of 0.178 .

Table 6: Regression result

Table 6: Regression result

\begin{tabular}{|c|c|c|c|}
\hline & $\begin{array}{l}\text { Unstandardized } \\
\text { Coefficients }\end{array}$ & $\mathbf{t}$ & Sig. \\
\hline & B & & \\
\hline (Constant) & 1.127 & 2.039 & $.044^{* *}$ \\
\hline Salary & .119 & 1.260 & .211 \\
\hline Job security and stability & .190 & 2.346 & $.021^{* *}$ \\
\hline Opportunities for advancement & .206 & 1.891 & $.062^{* *}$ \\
\hline Perceived prestige or status & .009 & .086 & .932 \\
\hline Students' perception on accounting field & .171 & 1.329 & $.187^{*}$ \\
\hline \multicolumn{4}{|l|}{ R Square = .188 } \\
\hline \multicolumn{4}{|l|}{ Adjusted R Square = .146} \\
\hline \multicolumn{4}{|l|}{$F$ Value $=.492$} \\
\hline$P$ value $=.001$ & & & \\
\hline
\end{tabular}

\footnotetext{
* $\quad$ Significant at the $10 \%$ level (2-tailed)

** $\quad$ Significant at the $5 \%$ level (2-tailed)

*** Significant at the $1 \%$ level (2-tailed)
}

As shows in Table 6, job security and stability is positively and significantly related to the students' career choice as professional accountants at 5\% level of confidence (2-tailed). This result is consistent with earlier findings by Ahmadi et al. (1995) and Germanou and Hassall (2009). Ahmadi et al (1995) finds that job security and stability is one of the factors that is important to accountants during job selection. Germanou and Hassal find that job security is significantly related to Malaysian students' intention to pursue accounting career.

Another significant factor that influences the career intention to become professional accountant in Malaysia is the opportunities for advancement. This result is consistent with the 
result of earlier studies by Germanou and Hassall (2009), Ahmadi et al. (1995) and Trump and Hendrickson (1970). Ahmadi et al. (1995) find that career enhancement is an important factor for females accounting students in their job selection decision. Accounting students place opportunities for enhancement as either the first or second most important criterion in career choice (Trump and Hendrickson, 1970). Opportunity for advancement is also significantly related to accounting students' intention to pursue accounting career (Germanou and Hassall, 2009).

Another variable, students' perceptions towards accounting professional examination is also positively and significantly related to the students' career choice as professional accountants at $10 \%$ level of confidence (2-tailed). This result is consistent with the earlier finding by Germanou and Hassall (2009). Germanou and Hassall find that there is a significant correlation between the students' perception and their intention to pursue a career in the profession. The interview sessions with the respondents also reveals that their perceptions influence their intention to pursue or not to pursue professional qualification. Those who have the intention to pursue the exam have these perceptions about the exam:

"I want to be a professional and get more salary"

"Professional accountant is highly valued by the society"

"Taking and passing professional examination will increase my confidence."

While those who do not have the intention to take the exam have these perceptions about the exam when interviewed:

"Professional qualification is too difficult to pass"

"It is stressful to pursue professional qualification such as ACCA, CIMA and others"

This finding suggest the importance of accounting educators (lecturers and universities) and practitioners, as well as the related ministry to actively promoting and providing information about being the professional accountants to the students, in order to positively influence their perception and attract them to be a professional.

\section{Conclusion and limitations of the study}

The objective of this study is to examine the factors that influence the accounting students in pursuing the professional examination. The results indicate that job stability and security, opportunities for advancement and the students' perceptions towards the profession will significantly influence their decision to pursue professional examination. This result is consistent with the earlier studies by Sugahara et al. (2008) and Germanou and Hassall (2009).

This study also suggests that the educators and universities must play their role to positively influence and motivate the students to pursue professional examination. The favourable information about the profession may attract the potential students to take the challenge. 
This study has its limitations. First, the sample of this study is quite limited, as it comprises of students from one public university only, future study should extend it to include students from other public as well as private universities. Secondly, although the regression result finds significant relationships in several of these variables, the smaller adjusted R-squared of the regression analysis implies the existence of other influential variables. Thus, future study should consider other variables such as culture, academic performance, marital status and other personal values.

Despite these limitations, this study contributes to the literature by providing information to the universities and profession on the factors that influence the students in their career choice as professional accountants.

\section{References}

Abdullah, M. (2001). Professional accountant: Malay students' bad perceptions. [Akauntan professional: Pelajar Melayu bertanggapan lapuk]. Utusan Malaysia. Retrieved on August 10, 2010 from http://www.utusan.com.my/utusan /info.asp?y= $2009 \& \mathrm{dt}=0713 \& \mathrm{pub}=\mathrm{Utu}$ an Malaysia\&sec=Ekonomi\&pg=ek_04.htm

Ahmadi, M., Helms, M.M., \& Nodoushani, P. (1995). A factor analytic approach profiling job selection differences of male and female accountants. Managerial Auditing Journal, 10(7), 17-24. http://dx.doi.org/10.1108/02686909510147200

Albrecht, W.S., \& Sack, R.J. (2000) Accounting education: charting the course through a perilous future, Accounting Education series, No 16, American Accounting Association, Sarasota, FL

Carpenter, C. G., \& Strawser, R. H. (1970) Job Selection Preferences of Accounting Student. Journal of Accountancy, 29(6) 84-86.

Field, A. (2005). Factors Analysis Using SPSS. C8057 (Research Method II): Factor Analyse on SPSS.

Germanou, E., \& Hassall, T. (2009). Students' perceptions of accounting profession: work value approach, Asian Review of Accounting, 17(2), 136-148. http://dx.doi.org/10.1108/13217340910975279

Ghani, E. K., Said, J., Nasir, N. M. \& Jusoff, K. (2008). The $21^{\text {st }}$ Century Accounting Career from the Perspective of the Malaysian Universities Students, Asian Social Science, 4(8): $73-83$

Gujarati, D.N. (2003). Basic econometrics (4th ed.). Singapore: McGraw Hill.

Ho, R. (2006). Handbook of univariate and multivariate data analysis and interpretation with SPSS. Boca Raton: Chapman \& Hall/ CRC. http://dx.doi.org/10.1201/9781420011111

Horowitz, K., \& Riley, T. (1990). How do accounting students see us. Accountancy, September, 75-79. 
Jackling, B. (2002). Are negative perceptions of the accounting profession perpetuated by the introductory accounting course? - An Australian study. Asian Review of Accounting, 10 (2), 62-80. http://dx.doi.org/10.1108/eb060758

Kline, R.B. (2005). Principles and practice of Structural Equation Modelling (2nd ed.). New York: The Guilford Press

Kloot, L., Marles, K., \& Vinen, D. (1999). Professional accounting qualification choices: Do gender, ethnicity, university and selection process matter? Asian Review Accounting, 7 (1), 131-143. http://dx.doi.org/10.1108/eb060709

Lanson, J. (2010). Malaysia needs 60,000 accountants. Utusan Malaysia. Retrieved on August 10, 2010 from http:/www.utusan.com.my/utusan /info.asp?y= $2009 \& \mathrm{dt}=0713 \& \mathrm{pub}=\mathrm{Utu}$ an Malaysia\&sec $=$ Ekonomi\&

Malaysia kekurangan akauntan bertauliah [Malaysia lack of certified accountants] (2009, July 13). Utusan Malaysia. Retrieved on August 10,2010from

http://www.utusan.com.my/utusan $\quad /$ info.asp? $=\quad 2009 \& d t=0713 \& p u b=U t u \quad$ an Malaysia\&sec=Ekonomi\&pg=ek_04.htm

Malthus, S., \& Fowler, C. (2009) Perception of Accounting: a quantitative New Zealand study. Pacific Accounting Review, 21(1), 26-47. http://dx.doi.org/10.1108/01140580910956849

MIA wants accountants to have professional qualification (2004). Utusan Malaysia. Retrieved on August 10, 2010 from http://www.utusan.com.my/utusan /info.asp?y= $2009 \& \mathrm{dt}=0713 \& \mathrm{pub}=\mathrm{Utu}$ an Malaysia\&sec $=$ Ekonomi

Miller, J., \& Wheeler, K. (1992) Unravelling the mysteries of gender differences in intention to leave the organisation. Journal of Organisational behaviour, September 1992, 465-478. http://dx.doi.org/10.1002/job.4030130504

Omar, N. (2009). Factors influencing the diploma in accounting (DIA) students'decision to pursue professional accounting programmmes.

Said, J., Ghani, E. K., Hashim, A., \& Nasir, N. M. (2004) Perception Towards Accounting Career Among Malaysian Undergraduates. National Accounting Research Journal, 2(1), $31-42$.

Steadman, G., \& Huang, A. (1996) Factors influencing choice of accounting discipline culture and gender differences. Accounting Research Journal, 9(1), 82-89.

Sugahara, S., \& Boland, G. (2006) Perceptions of the certified public accountants by accounting and non-accounting tertiary students in Japan. Asian Review of Accounting, 14 (1/2), 149-167. http://dx.doi.org/10.1108/13217340610729518

Sugahara, S., Hiramatsu, K., \& Boland, G. (2008). The factors influencing accounting students' career intention to become a Certified Public Accountant in Japan. Asian Review of Accounting, 17(1), 5-22. http://dx.doi.org/10.1108/13217340910956487 
Trump G.W., \& Hendrickson H.S. (1970). Job selection preferences of accounting students. The Journal of Accountancy, June, 84-86.

Wheeler, K.G. (1983). Perception of labour market variables by college students in business, education and psychology. Journal of Vocational Behaviour, 22, 1-11. http://dx.doi.org/10.1016/0001-8791(83)90002-7

\section{Copyright Disclaimer}

Copyright reserved by the author(s).

This article is an open-access article distributed under the terms and conditions of the Creative Commons Attribution license (http://creativecommons.org/licenses/by/3.0/). 